BRITISH MEDICAL JOURNAL 28 OCTOBER 1978

irrespective of ethnic origin. They should be encouraged to breast-feed their babies for at least two weeks and preferably for the first four to six months.

After arriving in the UK most Asians adopted British habits of introducing solids into the infant's diet; the Chinese, however, did not make a similar adjustment. The Africans did not appear to be much affected by standard feeding practices in Britain and, like the Scots, added solids to most of the infants' diets by 6 months. The tendency of the Scottish mothers to bottle-feed and to introduce cereals or other solid foods to the diet at an early stage followed the current trend in the country.

In view of the many African and Chinese children in the survey who had never received vitamin supplements we recommend that all parents be encouraged to give vitamins to their children up to school age. The finding of rickets in $12.5 \%$ of Asian children in this survey suggests a serious problem that warrants immediate action ${ }^{1}$; the disease does not seem to be a problem with African, Chinese, and Scottish children. To prevent rickets all Asian children should be encouraged to take vitamin D supplement. A preparation providing $7.5 \mu \mathrm{g}$ cholecalciferol (300 IU) daily would probably be adequate and should be recommended for use between the ages of 3 months and 16 years.

We are grateful to our liaison health visitors Miss B MacGregor, Miss S Alpine, and Mrs E Sharp and area health visitors for organising the survey clinic. We thank Miss Stella Reekie and Miss K Chung for providing Hindi- and Chinese-speaking interpreters; the other members of the dietetic department for their help and encouragement; and the parents and children, who so willingly came to the survey clinic.

Requests for reprints should be addressed to Dr K M Goel, Royal Hospital for Sick Children, Yorkhill, Glasgow G3 8SJ.

\section{References}

1 Goel, K M, et al, Lancet, 1976, 1, 1141.

2 Goel, K M, et al, British Medical fournal, 1977, 1, 665.

${ }^{3}$ Goel, K M, et al, Health Bulletin (Edinburgh), 1978, 36, 176.

${ }^{4}$ Evans, E, et al, Archives of Disease in Childhood, 1976, 51, 608.

(Accepted 25 August 1978)

\title{
Outcome of pregnancy after amniocentesis for chromosome analysis
}

\author{
JOHN PHILIP, JENS BANG
}

British Medical fournal, 1978, 2, 1183-1184

\section{Summary and conclusions}

A consecutive series of 1177 pregnant women examined by amniocentesis for chromosomal abnormalities delivered 1039 live-born babies weighing over $2500 \mathrm{~g}$ and 79 live-born babies weighing under $2500 \mathrm{~g}$. Twentysix abortions were induced (2.2\%)-13 (1.1\%) because of chromosomal abnormalities-and 28 women (2.4\%) aborted spontaneously; in these cases chromosomes were normal.

Analysis of all spontaneous abortions in the series suggested that $0 \cdot 3-0 \cdot 7 \%$ might have resulted from amniocentesis.

\section{Introduction}

In a consecutive series of 1086 pregnancies the overall incidence of chromosomal abnormalities was $1.4^{\circ} \%$, there being no appreciable difference between low-risk and high-risk groups. This appeared to be an important argument for offering amniocentesis for chromosome analysis to all pregnant women. ${ }^{1}$

\footnotetext{
Section of Clinical Genetics, Department of Obstetrics and Gynaecology YA, and Department of Paediatrics, University of Copenhagen, Denmark

JOHN PHILIP, MD, professor of gynaecology

Department of Obstetrics, St Joseph's Hospital, Copenhagen JENS BANG, MD, head of department
}

Justification for such a policy, however, must depend on complications of the procedure. We have therefore reviewed the outcome of 1177 pregnancies examined by amniocentesis and report the results.

\section{Subjects and methods}

During 1 March 1973 to 1 May 1977, 1179 samples of amniotic fluid from 1177 women were received for analysis by the chromosome laboratory, Rigshospitalet. Most were obtained in the ultrasound laboratory at St Joseph's Hospital. Of the 1177 women, six had twin pregnancies but only two of these were detected by ultrasound before amniocentesis. Amniocentesis was carried out as described for singleton ${ }^{2}$ and twin $^{3}$ pregnancies.

The following data were obtained by questionnaire completed at the time of delivery in the department where delivery took place. Other information in the questionnaire is not included here.

\section{Results}

Table I gives the outcome of the 1177 pregnancies. Of all 1183 infants in the series, $1118(94.5 \%)$ were born alive: $1039(87.8 \%)$ weighed over $2500 \mathrm{~g}$, and $79(6 \cdot 7 \%)$ under $2500 \mathrm{~g}$. Twenty-six terminations were performed, 13 because of chromosomal abnormalities, and the rest because of raised $\alpha$-fetoprotein concentrations, rubella infections, male fetuses in families with $\mathrm{X}$-linked disease, maternal diabetes, and adrenogenital syndrome. In one of the four cases of twins not detected by ultrasound before amniocentesis a liveborn infant with Down's syndrome was delivered.

\section{SPONTANEOUS ABORTIONS}

Twenty-eight pregnancies $(2.4 \%)$ ended in spontaneous abortion (table II). Although amniocentesis was usually performed during or after the 16th week of gestation, in about a quarter of these cases it was 
TABLE I-Outcome of 1177 pregnancies after amniocentesis

\begin{tabular}{|c|c|c|c|c|c|c|}
\hline & \multicolumn{2}{|c|}{ Born alive } & \multirow{2}{*}{ Stillborn } & \multirow{2}{*}{$\begin{array}{l}\text { Spontaneous } \\
\text { abortions }\end{array}$} & \multirow{2}{*}{$\begin{array}{c}\text { Induced } \\
\text { abortions }\end{array}$} & \multirow{2}{*}{$\begin{array}{c}\text { Total } \\
\text { infants* }\end{array}$} \\
\hline & $>2500 \mathrm{~g}$ & $<2500_{\mathrm{g}}$ & & & & \\
\hline No $(\%)$ of infants & $1039(87 \cdot 8)$ & $79(6 \cdot 7)$ & $11(0.9)$ & $28(2 \cdot 4)$ & $26(2 \cdot 2)$ & $1183(100 \cdot 0)$ \\
\hline
\end{tabular}

*Six cases were twin pregnancies, four of which were unrecognised at the time of amniocentesis; one of these twins had Down's syndrome.

TABLE II-Indications for amniocentesis and incidences of spontaneous abortion

\begin{tabular}{|c|c|c|c|c|c|}
\hline & & $\begin{array}{c}\text { Maternal } \\
\text { age } \\
>40\end{array}$ & $\begin{array}{c}\text { Maternal } \\
\text { age } \\
35-9\end{array}$ & $\begin{array}{l}\text { Other } \\
\text { (maternal } \\
\text { age } \\
<35)\end{array}$ & Total \\
\hline $\begin{array}{l}\text { No of samples obtained by } \\
\text { amniocentesis } \\
\text { No }(\%) \text { of spontaneous } \\
\text { abortions .. }\end{array}$ & $\begin{array}{l}\cdots \\
\ldots\end{array}$ & $\begin{array}{l}256 \\
\quad 8(3 \cdot 1)\end{array}$ & $\begin{array}{l}469 \\
14(3 \cdot 0)\end{array}$ & $\begin{array}{l}454 \\
\quad 6(1 \cdot 3)\end{array}$ & $\begin{array}{l}1179^{*} \\
28(2 \cdot 4)\end{array}$ \\
\hline
\end{tabular}

*Includes two cases in which twins were diagnosed before amniocentesis.

TABLE III-Percentage incidence of fetal loss in different series in which amniocentesis was and was not used

\begin{tabular}{|c|c|c|c|}
\hline & $\begin{array}{l}\text { Spontaneous } \\
\text { abortion }\end{array}$ & Stillbirth & Total \\
\hline \multicolumn{4}{|c|}{ Amniocentesis used } \\
\hline NICHD, 1976 (USA) $^{8} \quad \cdot$ & & & $\begin{array}{c}3.5 \\
\text { (controls 3.2) }\end{array}$ \\
\hline $\begin{array}{l}\text { Galjard, } 1976 \text { (Europe) }{ }^{7} \\
\text { Collaborative study, } 1977\end{array}$ & $1 \cdot 4$ & & $\begin{array}{c}\text { (controls } 3 \cdot 2) \\
1 \cdot 4\end{array}$ \\
\hline $\begin{array}{l}\text { (Canada) } \\
\text { Present series (Copenhagen) }\end{array}$ & $\begin{array}{l}1 \cdot 0 \\
2 \cdot 4\end{array}$ & $\begin{array}{l}2 \cdot 3 \\
0.9\end{array}$ & $\begin{array}{l}3 \cdot 3 \\
3 \cdot 3\end{array}$ \\
\hline $\begin{array}{l}\text { Shapiro et al, } 1962(\text { New York } \\
\text { Obel (Copenhagen) }\end{array}$ & $\begin{array}{c}\text { nniocentesis not } \\
3 \cdot 2 \\
2 \cdot 7\end{array}$ & & $\begin{array}{l}3 \cdot 2 * \\
2 \cdot 7 \dagger\end{array}$ \\
\hline
\end{tabular}

*After 15 th week of gestation.

tAll ages.

performed sooner. The earlier amniocentesis is performed, the more likely is the mother to have a spontaneous abortion. In three of the 28 cases $(10 \cdot 7 \%)$ repeated punctures were necessary owing to difficulty in obtaining fluid or in culturing cells. The overall incidence of repeated punctures in the series was 3\% (see below). Only six of the spontaneous abortions occurred in women aged under 35 (table II). The mean age in all 28 cases was 35 years, range 23-49.

Three of the 1179 women $(0.3 \%)$ had their first symptom of abortion within eight days of amniocentesis. Eight $(0.7 \%)$ had their first symptom between eight days and three weeks and $17(1.4 \%)$ after three weeks. Eleven of the 28 women already had factors associated with an increased risk of abortion. Eight others probably had such factors. Risk factors noted in the series were bleeding, cervical insufficiency, hydrocephalus, twins, intrauterine device in situ, and abnormalities of the placenta.

None of the fetuses aborted spontaneously had a chromosomal abnormality.

\section{Discussion}

This investigation was prompted by two questions: Does amniocentesis in early pregnancy lead to spontaneous abortion? and, if so, What would be the acceptable incidence in a series aimed at preventing the birth of abnormal children ? We cannot provide a definitive answer, however, because the study was uncontrolled. In Denmark almost all women offered amniocentesis will accept, and it must be offered when a fetus is at risk.

Other workers have shown that the risk of abortion increases when amniocentesis proves difficult to perform or needs to be repeated. ${ }^{4}$ In our centre immediate complications are few. Out of 1760 consecutive amniocenteses performed during March 1973 to February 1978, $42(2 \cdot 4 \%)$ produced macroscopically blood-stained fluid. In 32 cases $(1.8 \%)$ two punctures were made the same day, and in $19(1 \cdot 1 \%)$ a second puncture was made a week later. In the second two-thirds of cases, by which time the obstetricians had gained optimum experience with the technique, only $1.5 \%$ of samples contained macroscopic blood and $0.2 \%$ of patients needed a second puncture a week later.

The incidence of fetal loss after amniocentesis may be assessed indirectly by comparison with figures for prematurity and abortions. In our series the incidence of premature births was $6.7 \%$, while that for the whole of Denmark during 1976 was $6.0 \%$ (Danmarks Statistik). During 1974-5 in this department, which serves a selected high-risk group, the incidence was $8.9^{\circ}{ }_{0}$

Obel $^{5}$ in Copenhagen and Shapiro et $a l^{6}$ in New York, who analysed spontaneous abortion rates among women of different ages and at various periods of gestation, reported similar incidences among women not examined by amniocentesis to that found in our series (table III). Three comparative studies of spontaneous abortion rates have been conducted among women investigated for chromosomal abnormalities in the fetus with and without amniocentesis. ${ }^{4}{ }^{8}$ One of these ${ }^{8}$ was a controlled study and showed no appreciable difference in incidence between the two groups (table III). Such comparisons with other series are difficult, however, because of differences in age, parity, smoking habits, selection of patients, etc.

Of the 28 women in our series who aborted spontaneously after amniocentesis, 11 were probably already at risk of aborting. Of the remainder, eight $\left(0 \cdot 7^{\circ}\right.$ of all mothers $)$ had their first symptom of abortion within three weeks after the procedure. Thus if three weeks is considered to be a reasonable limit these cases might have been causally associated with amniocentesis. Three women without risk factors associated with abortion had their first symptom within one week after the procedure. Thus if this is regarded as a reasonable time limit, $0.25 \%$ of all mothers might have aborted as a result of amniocentesis.

Our findings suggest that amniocentesis in early pregnancy does entail a small risk of spontaneous abortion. Nevertheless, about $0.5 \%$ of newborn babies have chromosomal abnormalities. Confining amniocentesis to women over 35 results in only 20$30 \%$ of cases of Down's syndrome being detected before birth. ${ }^{9}$

The overall incidence of abortion after the 15th week of pregnancy and independent of maternal age is $2 \cdot 0-2 \cdot 5 \%$. Our findings suggest that if all pregnant women undergo amniocentesis the incidence will increase by $0 \cdot 3-0 \cdot 7 \%$. This, however, must be weighed against the $70-80 \%$ of cases of Down's syndrome and even higher proportion of other genetic disorders that go unrecognised before birth.

We believe that provided finance is available amniocentesis should be offered to all pregnant women.

\section{References}

${ }^{1}$ Philip, J, et al, British Medical fournal, 1977, 2, 1117.

2 Bang, J, and Northeved, A, American fournal of Obstetrics and Gynecology, 1972, 114, 599

${ }^{3}$ Bang, J, Nielsen, H, and Philip, J, American fournal of Obstetrics and Gynecology, 1975, 123, 685.

${ }^{4}$ Canadian Collaborative Study, Canadian Medical Research Councu Report, No 5. Ottawa, CMRC, 1977.

${ }^{5}$ Obel, E, Risk of spontaneous abortion following legal abortion. To be published.

${ }^{6}$ Shapiro, S, et al, Milbank Memorial Fund Quarterly, 1962, 40, 7.

7 Galjard, H, Cytogenetics and Cell Genetics, 1976, 16, 453.

${ }^{8}$ NICHD, National Registry of Amniocentesis Study Group, fournal of the American Medical Association, 1976, 236, 1571.

${ }^{9}$ Mikkelsen, M, et al, Annals of Human Genetics, 1976, 40, 177.

(Accepted 30 August 1978) 